\title{
The Model Of Capability Toward The Intention To Use Internet Banking In Indonesia
}

\author{
Nurbaiti, Basu Swastha Dharmmesta, Ayi Ahadiyat, Ribhan
}

Doctoral Management Student

Faculty of Economics and Business, University of Lampung

Article History: Received:11 January 2021; Accepted: 27 February 2021; Published online: 5 April 2021

\begin{abstract}
The rapid advancement of information technology encourages business needs to use technology to serve consumers. Electronic transaction in the form of internet banking is a new way of transfer that changes the form of services from human technology to information technology. This study aims to examine the capability model of the intention to use internet banking in Indonesia. This study is quantitative in the form of a survey study. The sample in this study were non-user customers and prospective internet banking users in both private and state-owned banks. The data were analyzed using the partial least square (PLS). This study contributes to the development of internet banking marketing to improve features, security and service quality. The results show that all hypotheses indicate a positive and significant effect.
\end{abstract}

Keywords : Capability, Perceived Ease of Use, TAM, and Internet Banking

\section{Introduction}

\subsection{Background}

The very rapid advancement of information technology encourages business needs to use technology to serve consumers. The development of information technology has transformed the strategy of business including banking by prioritizing information technology in transaction process and services for consumers. In addition, the development of information technology also encourages innovation in the service sector, including banking service. The development of internet banking services is in line with the increasingly rapid growth of information technology. The innovations of transaction and service are an integral part of banking development. This aims to improve service quality to be more effective and efficient. One of the internet-based transactions that is currently a concern in banking is internet banking (Chan and Ming, 2004). As a new strategy, electronic transaction in the form of internet banking is a new way of transfer that changes the form of services from human technology to information technology.

On the other hand, according to APJII (2020), the use of internet banking services is at the lowest level with only $16.75 \%$. This shows that the demand for internet banking services in Indonesia is still low. The Financial Services Authority as a bank supervisory authority has a strong responsibility in ensuring that banks implement internet banking services with prudential banking principles, risk management and customer protection as the dependency on technology and third parties is very high. The government has issued a policy on digital transactions, but only a small proportion of people use this service. Internet banking provides convenience and benefits; however, the current data shows that internet banking users are still low. This means that convenience and benefits have not solved the problem.

Davis (1985) in Chuttur (2009) proposed that system use, which was previously directly influenced by system features and user capabilities, can be explained or predicted by user motivation. System use is a response that can be explained or predicted by user motivation which in turn is directly influenced by external stimuli including system features and capabilities. To be clearer, it is described in Figure 1.

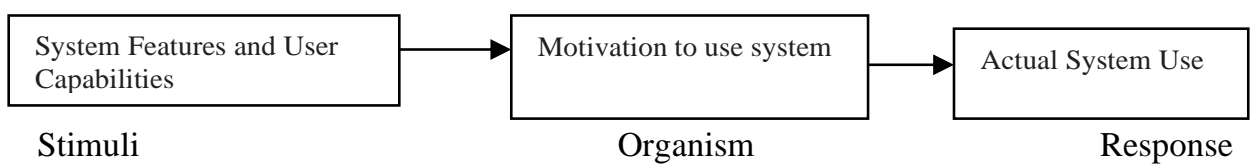

Figure. 1. Conceptual Model of Technology Acceptance

Source: Davis (1985) in Chuttur (2009)

Therefore, banking efforts are needed to increase the use of internet banking services. This is because most internet users think that internet banking is risky. So, it is necessary to examine the factors that can affect the use of internet banking. Most researchers focus more on the benefits and ease of use in intention to use information technology, including internet banking. 
The description above shows several gaps related to findings that there are still weaknesses between the perceived ease of use and the perceived usefulness which are insufficient to make technology acceptance so it is assumed that there are other influencing factors. When using internet banking, there is no direct contact between humans. However, if an obstacle occurs, someone must be able to solve it.

System use is a response that can be explained or predicted by the user's motivation, which in turn is directly stimulated by the user's ability so that it is assumed that there will be a relation with the intention to use internet banking. With the perceived ease of use, a high-capability person will use a system easier which is assumed to affect the intention to use internet banking.

The purpose of this study is to examine the capability of the intention to use internet banking in Indonesia. More specifically, this study (1) examine the role of individual capabilities in the influence of perceived ease of use, (2) examine the role of individual capabilities in the influence of intention to use internet banking, (3) examine the mediating effect of perceived ease of use in the relation between capability and the intention to use internet banking. This study is expected to contribute as a basis for policymaking for the government and banks regarding the use of internet banking. In addition, this study is also expected to provide practical contributions in the development of internet banking marketing for banks to improve features, security and service quality.

\section{Literature Review, Research Framework and Hypothesis Development 2.1 Literature Review}

a. Theory of Reasoned Action

Theory of Reasoned Action (TRA) developed by Fishbein and Ajzen $(1975,1980)$, has the principle of determining how to measure the components of attitude towards relevant behavior, distinguishing between beliefs and attitudes, and determining external stimuli. Therefore, the TRA model triggers user reactions and perceptions of the information system to determine the user's attitudes and behavior. TRA formulates that an individual's tendency to act is a major factor in a person's behavior. The intention to act depends on the attitude towards the behavior and the subjective norms in the surroundings. Attitude on behavior is positive and negative feelings in carrying out the targeted behavior, whereas subjective norms are defined as a person's perception about whether he should or should not perform certain behaviors.

\section{b. Theory of Planned Behavior}

This theory relies on social psychology revealed by Ajzen (1985) as an extension of TRA. This theory argues that actual behavior is determined by the intention to act which in turn is influenced by individual attitudes, subjective norms and perceived behavioral control (Ajzen, 1991 in Teo and Pok, 2003). TPB (Theory of Planned Behavior) was developed to expand TRA in predicting and understanding behavior under the control on incomplete willingness. In addition to behavioral beliefs, TPB adds two important constructs in explaining behavior including subjective norm (normative belief) and perceived behavioral control (control belief).

\section{c. Technology Acceptance Model (TAM)}

TAM describes a causal relationship between belief (in the benefits of an information system and its ease of use), behavior, needs, and actual use of an information system. TAM is a research model that can be used to predict the adoption of information technology introduced by Davis in 1989. TAM aims to explain and measure user acceptance of an information system. TAM provides a theoretical basis for knowing the influencing factors of a technology acceptance in an organization; the factor is perceived ease of use. In Davis (1989) states that ease means freedom from $\mathrm{d}=$ ifficulty or great effort. Then, perceived ease of use is defined by the degree to which a person believes that using a particular system would be free of effort. Related to information system, it means that the user believes that the information system is easy to use so that it does not require big effort and will be no difficulties. This includes the ease of using the information system according to the user's willingness. Davis (1989) found that perceived ease of use can explain why users use the system and the new system that users can accept.

\subsection{Research Framework and Hypothesis Development}

Capability is the ability that comes from the word "able" which means being able to do something, while ability means proficiency or power (Kamus Besar Bahasa Indonesia, 1989: 552-553). Ability means the capacity of an individual to perform various tasks in a job (Robbins et al., 2009). From this understanding, it can be concluded that ability is the power of an individual to master a skill and is used to carry out various tasks in a job. According to Kamus Besar Bahasa Indonesia (2014), capability is the same as competence. However, the meaning of capability is not only limited to having skills but also understanding in more detail so that someone can completely master his abilities including the weakness and how to overcome it. According to Baker and Sinkula (2005), is a set of specific skills, procedures, and processes to utilize resources and take competitive advantages. In brief, Individual capability 
is an ability that is more than skill at something that becomes a competitive advantage and ability mastery from a weak point.

Based on the description above, the research model of capability concept on the intention to use internet banking can be seen in the following figure:

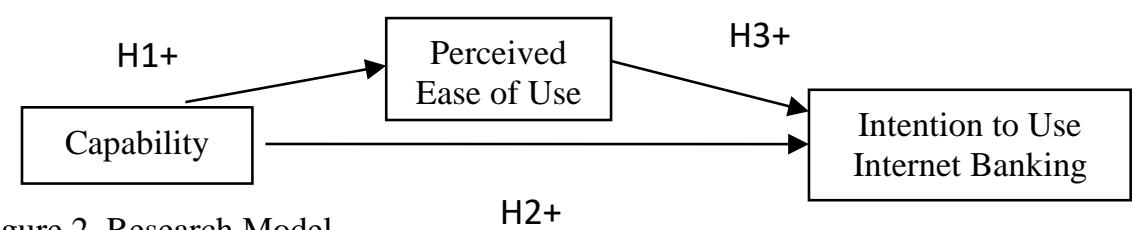

Figure 2. Research Model

The ability in technology will underlie certain innovations and it is essential to trigger a response. The individual ability to use computer to complete tasks is a significant influencing factor of the use of an information system (Compeau and Higgins, 1995, Adamson and Shine, 2003). Dynamic capability is beneficial for the concept of innovation that identifies ability through values and its implementation (Hyunsuk Lee and Donna Kelley, 2008). John and Rotimi (2014) found that there is a significant relationship between internet banking and customer satisfaction. Ejdys (2018) shows that ease of use, general trust level, respondents and institutional trust also have a significant effect. Ease of use is the consumer's perception that transactions using internet banking will be more effective and efficient.

In several studies on information technology, perceived ease of use has been identified as the main construct for examining and assessing user's technology acceptance. Thus, the hypothesis can be formulated as follows.

H1: Capability positively affects perceived ease of use

H2: Capability positively affects the intention to use internet banking

H3: Perceived ease of use strengthen the effect of capability on the intention to use internet banking

\section{Research Methodology}

a. Population dan Sample

In this study, the population is the internet users in Indonesia. Furthermore, 200 respondents who have savings in banks but have not used internet banking services were selected using purposive sampling technique. This sample size has met the minimum sample size required, i.e., 200-600 respondents (Kline, 2005; Foster et al., 2006; Hair et al., 2014; Ghozali, 2013). In this study, the covariance-based Structural Equation Model (SEM) requires a sample size at least 10 times the number of observed variables.

\section{b. Data Collection}

Questionnaire is a pre-formulated set of written questions in which respondents record their answers which are usually the closest alternatives. The questionnaire is an efficient data collection technique when the researcher knows exactly what he needs and how the interesting way to measure the variables. Questionnaire can be administered privately, sent to respondents, or now it can be distributed electronically (2003: 236). This study is quantitative. Therefore, the questionnaire consists of closed statements with alternative answers to choose from.

\section{c. Definition and Operationalization of Research Variables \\ Independent variable}

Capability is individual ability to master a skill used to do various tasks in a job (Robins and Timothy, 2009). The capability is measured by five indicators including (1) the use of a computer or smartphone, (2) the use of internet as a technology that helps banking transactions, (3) the ability to use technology for banking transactions, (4) the ability to use communication technology and (5) the ability that influences income differences.

\section{Mediating Variable}

The perceived ease of use is the use of information systems in accordance with the user's intention (Davis, 1989). In this study, the ease of use is measured by five indicators, including (1) the convenience provided by internet banking in carrying out daily banking transactions, (2) the improvement transaction experience provided by internet banking, (3) the convenience to get the needs in banking transaction by internet banking, (4) great control over banking transactions provided by internet banking, and (5) the clarity and convenience to understand internet banking transactions. 


\section{Dependent Variable}

Intention is a person's desire to perform a certain behavior (Hartono, 2007). Internet banking is a banking service for bank customers to request and get information as well as to conduct banking transactions through computers and smartphones with internet (Suriya et al, 2012). The intention to use internet banking is measured by four indicators including (1) the opinion that internet banking has a positive impact, (2) the possibility to use internet banking soon, (3) the willingness that the use of internet banking will continue in the future, and (4) possibility to use internet banking even though there is only online instruction when transacting.

\section{d. Procedure of analysis}

In this study, the data were analyzed using Partial Least Square (PLS). PLS is a component or variant-based Structural Equation Modeling (SEM). The SEM analysis model applies a multivariate technique by combining multiple regression analysis and factor analysis (Hair et al, 2014: 546). According to (Ghozali, 2006), PLS is an alternative approach that shifts from a covariance-based to a variant-based SEM approach. The purpose of PLS is to help researchers in prediction and it is suitable for data collection using purposive sampling technique. The model defines latent variables as linear aggregates of the indicators. The weight estimation for creating a latent variable score component was obtained based on how the inner model (structural model) and the outer model (measurement model) are specified (Ghozali, 2006). The structural equation model in this study can be seen in Figure 3.

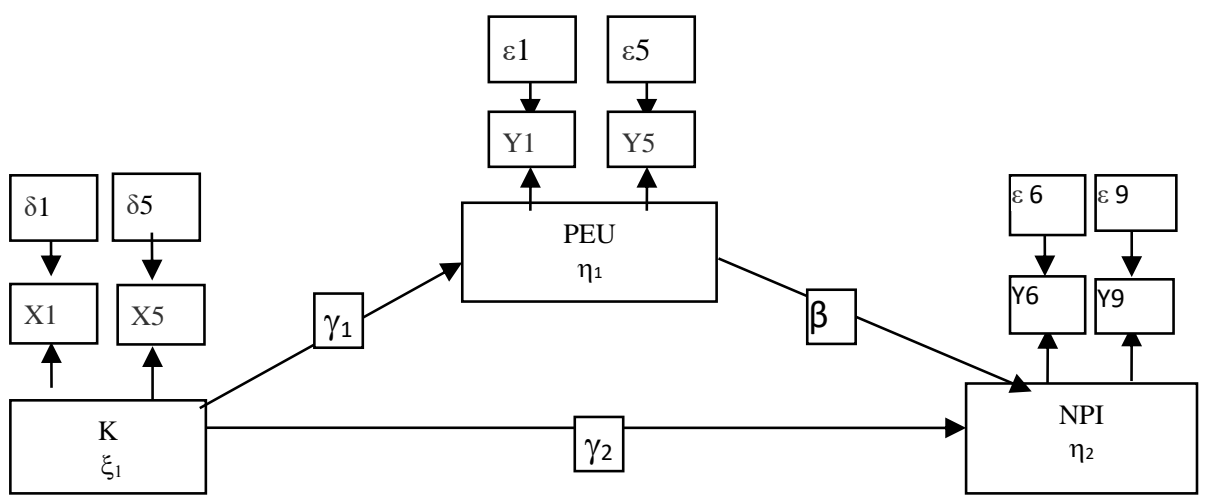

Figure 3. Structural Model

Based on Figure 3, the structural model equation is as follows.

Structural Model 1: $\square_{1}$ (PEU) $=\square_{1} \square_{\square \square}+\square_{\mathbf{1}}$

Structural Model $2: \square_{2}(\mathrm{NPI})=\square_{2} \square_{\square}+\beta \square_{1}+\square_{2}$

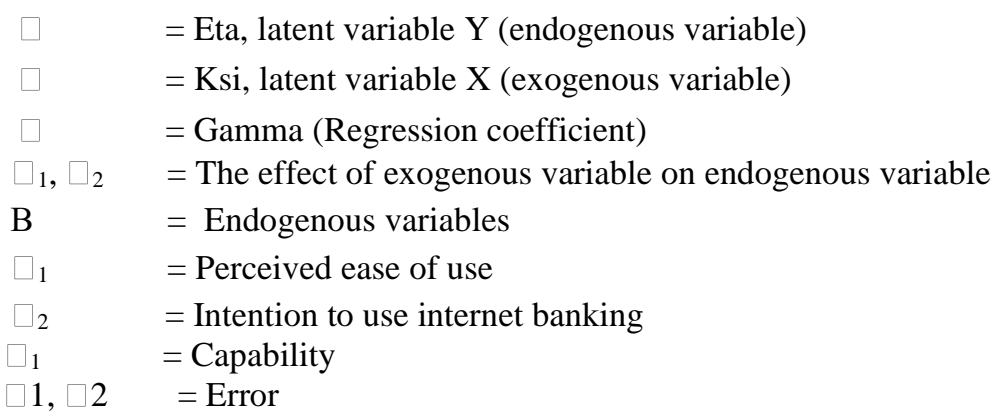

\section{RESULTS AND DISCUSSIONS}

Figure 4 shows the results of the analysis of the relationship between capability and intention to use internet banking in Indonesia mediated by perceived ease of use. 


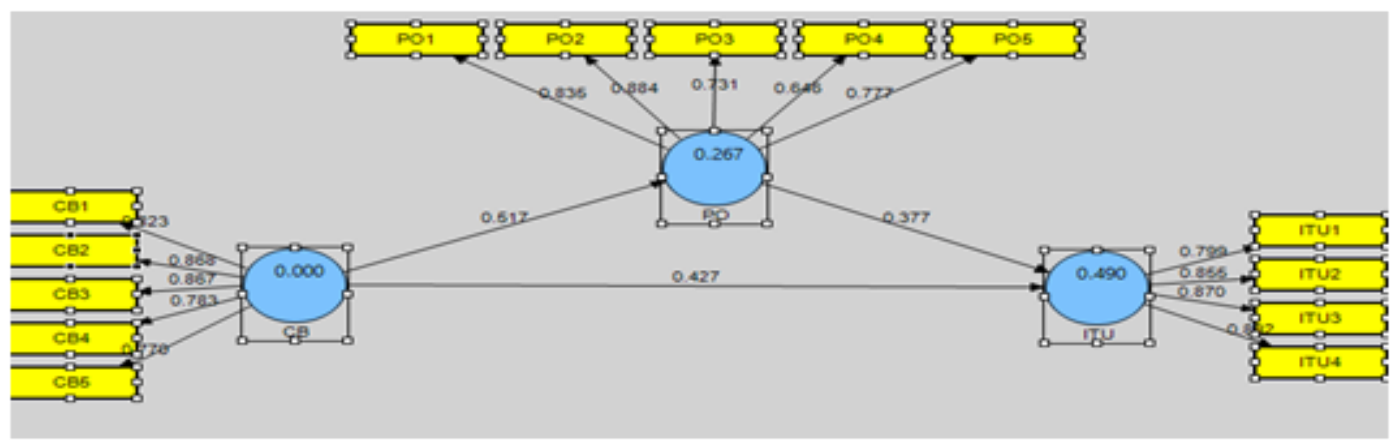

Figure 4. The Outer Model Value of Orginal Sample

Figure 4 shows that the value of outer loading and AVE is above 0.5. Likewise, the reliability value is above 0.7 while the Q-square value is 0.626542 which means that the model is good. More details can be seen in Table 2 .

Table 2. R-Square Value

\begin{tabular}{|l|c|}
\hline \multicolumn{1}{|c|}{ VARIABLE } & R-Squares \\
\hline Capability & - \\
\hline Perceived ease of use & 0.267479 \\
\hline Intention to use internet banking & 0.490175 \\
\hline
\end{tabular}

The calculation of Q-Square is as follows :

$$
\mathrm{Q}^{2}=1-(1-0.267479)(1-0.490175)=0.626542
$$

In addition to the feasibility, the above model also illustrates the relationship between the capability and the intention to use internet banking with a positive value of 0.427 , the relationship between the capability and the perceived ease of use is positive at 0.517 and the relationship between the perceived ease and the intention to use internet banking is positive at 0.377 . The mediation effect of the ease of use on the relationship between capability and intention to use internet banking is positive and significant. More details can be seen in Table 3.

Table 3. Result For Inner Weights

\begin{tabular}{|c|l|c|r|r|l|}
\hline $\begin{array}{c}\text { Hypoth } \\
\text { esis }\end{array}$ & \multicolumn{1}{|c|}{ Relation } & $\begin{array}{c}\text { Total Effects } \\
\text { Original Sample } \\
\text { Estimate (O) }\end{array}$ & $\begin{array}{c}\text { Indirect } \\
\text { Effects }\end{array}$ & $\begin{array}{c}\text { T-Statistics } \\
(\mid \mathrm{O} / \text { STERR } \\
)\end{array}$ & Decision \\
\hline H1 & CB -> PO & 0.517184 & 0 & 7.204149 & Accepted \\
\hline H2 & PO $->$ ITU & 0.376688 & 0 & 4.539158 & Accepted \\
\hline H3 & $\begin{array}{l}\text { CB -> PO } \\
\text { through ITU }\end{array}$ & 0.426661 & 0.19481 & 4.930167 & Accepted \\
\hline
\end{tabular}

The table above can be explained as follows

1 . The effect of capability on the ease of use

The relationship between the capability variable (CB) and the perceived ease of use (PO) shows a positive path coefficient value of 0.517184 and a t-value of 7.204149. So, there is a positive and significant effect of capability (CB) on the perceived ease of use (PO). the more a person understands his capabilities, the easier the system will be used. This result is in line with the research of Davis (1985) in Chuttur (2009).

2. The effect of perceived ease of use on the intention to use internet banking

The relationship between the intention to use internet banking (ITU) and perceived ease of use (PO) shows a positive path coefficient value (Total Effects) at 0.376688 with a t-count value of 4.539158 . This indicates that perceived ease of use (PO) has a positive and significant effect on the intention to use internet banking (NPI). The easier the system 
to use, the higher the intention to use internet banking. This result is in line with the research conducted by John and Rotimi (2014), and Ejdys (2018).

3. The effect of capability on the intention to use the internet through perceived ease of use

the relationship between the capability variable (CB) and the intention to use internet banking (ITU) shows the path coefficient value (Total Effects) from 0. 426661 to 0.621478 and t-count from 4.930167 to 10.155192. The changing value at 0.19481 in both the coefficient value and the t-value is the mediating effect of perceived ease of use. The mediation leads the relationship between capability (CB) and the intention to use internet banking (ITU) to be more positive and significant. This indicates that the more the capability to use technology and are supported by the perceived ease of use, the stronger individual's intention to use internet banking.

When customers are capable to learn and understand the use of internet banking faster, the use of internet banking will increase. The capabilities of internet banking users will make them think that the system is very easy to use. One of the conveniences of internet banking is that customers do not need to come to the bank for banking transactions. Therefore, the perceived ease of use is a mediator that strengthens the effect of capability on the intention to use internet banking. Bank customers will find it easier to use the system when they have the capability and perceived ease of use. So, they will have a positive attitude towards the internet banking system.

\section{Conclusion and Implication}

The study provides references for the government and banks in increasing the use of internet banking. Besides, this study found that the capability has a significant positive effect on perceived ease of use. Perceived ease of use has a significant positive effect on the intention to use internet banking. Mediated by perceived ease of use, the capability has a significant positive effect on the intention to use internet banking.

In order to optimize the use of internet banking in Indonesia, banks and the government need to regularly educate banking customers about internet banking, especially the convenience of and how to use it. This is because the higher the customer capability, the higher the intention to use internet banking.

\section{REFERENCES}

1. Abdulkadir, N., Galoji, S.I., Razak, R.B.A. 2013. An Investigation into the Adoption of Mobile Banking in Malaysia. American Journal of Economics. Vol. 3, No.3. pp, 153-158.

2. Abdullah, F.S., Alshammari, F.H., Alnaqeib, R., Jalab, H.A., Zaidan A.A., Zaidan B.B. 2010. Analytical Study on Internet Banking Systems. Journal of computing, Vol. 2, No. 6. pp, 140-146.

3. Adamson, I., and Shine, J. 2003. Extending the New Technology Acceptance Model to Measure the End User Information Systems Satisfaction in a Mandatory Environment: A Banks Treasury. Technolgy Analysis and Strategic Management. Vol. 15. No. 4. Pp. 441-455.

4. Aderonke, A . Adesina., Charles, K. Ayo. 2010. An Empirical Investigation of the Level of Users' Acceptance of E-banking in Nigeria. Journal of Internet Banking and Commerce. Vol.15, No.1. pp, 1-13.

5. Ajzen, Icek and Martin Fishbein. 1980. Understanding Attitudes and Predicting Social Behavior. Englewood: Prentice Hall

6. Alam,A., Siddiqui and Seeja. 2009. Proceedings of National Conference on Recent Developments in Computing and Its Applications, I. K. International Pvt Ltd, pp. 1-600.

7. Alsajjan, B., \& Dennis, C. 2010. Internet banking acceptance model: Cross-market examination. Journal of Business Research. Vol. 63, No. 9, pp. 957-963.

8. Amin, M., Rezaei, S. and Abolghasemi, M. (2014), "User satisfaction with mobile websites: the impact of perceived usefulness (PU), perceived ease of use (PEOU) and trust", Nankai Business Review International, Vol. 5, No. 3. pp. 258-274.

9. APJII (Asosiasi Penyelenggara Jasa Internet Indonesia). (2019). Survei Penetrasi dan Perilaku Pengguna Internet Indonesia.

10. Black, J. A., \& Champion, D. J., 2001. Metode dan masalah penelitian sosial (Terjemahan). Refika Aditaa, Bandung.

11. Chan, S., \& Ming, L. 2004. Understanding Internet Banking Adoption and Use Behavior. Journal of Global Information Management. Vol.12, No.3. pp. 21-23.

12. Chang, H., \& Chen, S. (2009). Consumer perception of interface quality, security, and loyalty in electronic commerce. Information and Management. Vol. 46, No. 7. Pp. 411-417

13. Chin, W. W., Peterson, R. A., \& Brown, S. P. (2008). Structural equation modeling in marketing: Some practical reminders. The Journal of Marketing Theory and Practice. Vol. 16, No. 4, Pp. 287-298. 
14. Chong, A.Y.L., Ooi, K.B., Lin, B., Tan., B.I. Online Banking Adoption: an Empirical Analysis. International Journal of Bank Marketing. Vol. 28, No. 4, pp, 267-287.

15. Chuttur, Mohammad. 2009. "Overview of The Technology Acceptance Model: Origins, Developments and Future Directions.” Sprouts, Working Papers on Information Systems, Vol.9, No.37. pp 121-126.

16. Davis, F., D., 1989. "Perceived Usefulness, Perceived Ease of Use, and User Acceptance of Information Technology, “ MIS Quartely. Vol. 13, No. 3. pp, 319-340.

17. Ejdys, J., 2018. Building Technology Trust in ICT Application at a University. International Journal of Emerging Markets, Vol. 35, No. 6. pp, 1120-1132.

18. Es Sajjade, Abdelghani dan Krsto Pandza. 2012 . Reconceptualising Dynamic Capabilities : A Design Science Study on the Role of Agency. Leeds University Business School.

19. Ferdinand, A., 2000. Structural Equation Modeling dalam penelitian Manajemen : Aplikasi model-model rumit dalam penelitian untuk Tesis S-2 dan Disertasi S-3 BP. Universitas Diponegoro (UNDIP), Semarang.

20. Gahtani, S.A. 2001. "The Applicability of TAM Outside North America: an Empirical Test in United Kingdom. " Information Resource Management Journal, Vol.14, pp, 37-46.

21. Ghozali, I. (2006). Structural Equation Modeling, Metode Alternatif dan Partial Least Square. Edisi 2. Semarang: Badan Penerbit Universitas Diponegoro.

22. Hair, J.F., Black, W.C., Babin, B.J., Anderson, R.E. and Tatham, R.L. 2006, Multivariate Data Analysis, Pearson Prentice Hall, Upper Saddle River, NY.

23. Hernandez, J.M.C., \& Mazzon, J.A. 2007. Adoption of internet banking: proposition and implementation of an integrated methodology approach. International Journal of Bank Marketing. Vol. 25. No. 2, pp. 72-88.

24. Ho, C. T. B., and Lin, W. C. (2010). Measuring the service quality of internet banking: scale development and validation. European Business Review. Vol. 22. No. 1, pp. 5-24.

25. Humphrey, M.S. 2014. Research Trends in the Diffusion of Internet Banking in Developing Countries. Journal of Internet Banking and Commerce. Vol. 19, No. 2.

26. Hyun and Steege. 2013. Development of a quantitative model of the impact of customers personality and perceptions on Internet banking use. Computer in Human Behavior. Vol. 29, pp 1133-1141.

27. IAMAI's Report on Online Banking 2006. Retrieved from: http://www.iamai.in Jayawardhena, C., 2004. Measurement of Service Quality in Internet banking: The Development of an Instrument. Journal of Marketing Management. Vol. 20, pp. 185-207.

28. Lee, M. 2009. Factors influencing the adoption of internet banking: An integration of TAM and TPB with perceived risk and perceived benefit. Electronic Commerce Research and Applications. Vol. 8, No. 3. Pp. $130-141$.

29. Lee, H., and Kelley, D. 2008. Building Dynamic Capabilities for Innovation: AN Exploratory Study of Key Management Practices. Journal Compilation Blackwell Publishing Ltd. Vol. 38, No.2, pp. 155-168.

30. Liao, Z., \& Cheung, M. T. (2008). Measuring consumer satisfaction in internet banking: A core framework. Communications of the ACM. Vol. 51, No. 4, pp. 47-51.

31. Lichtenstein, S., \&. Williamson, K. (2006). Understanding consumer adoption of Internet banking: An interpretive study in the Australian banking context. Journal of Electronic Commerce Research. Vol. 7, No. 2. Pp. 50.

32. Maditinos, D., Chatzoudes, D., Sarigiannidis, L. 2013. An Examination of The Critical Factors Affecting Consumer Acceptance of Online Banking a focus on the dimensions of risk. Journa; of Systems and Information Technology. Vol. 15, No. 1, pp, 97-116.

33. Magruk, A., 2017. Concept of uncertainty in relation to the foresight research. Engineering Management in Production and Service. Vol. 9. No. 1. Pp, 46-45.

34. Marakarkandy, B., Yajnik, N., Dasgupta, C. 2017. Enabling Internet Banking Adoption: An Empirical Examination with an Augmented Technology Acceptance Model (TAM). Journal of Enterprise Information Management. Vol. 30, No.2. pp, 263-294.

35. McKnight, DH., Chervany, N.L., 2005. What trust means in e commerce customer relationships: an interdisciplinary conceptual typology, International Journal of Electronic Commerce. Vol.6, No.2, pp. 3539

36. Norzaidi, M.D., Nor, I.M. and Sabrina, A.A., (2011). Customer's perception toward information security in Internet banking system in Malaysia. Australian Journal of Basic and Applied Sciences. Vol. 5, No. 9, pp. $101-112$.

37. Ozdemir, S and Trott, P. 2009. Exploring the adoption of a service innovation: A study of Internet banking adopters and non adopters. Journal of Financial Services Marketing. Vol. 13, No. 4, pp. 284-299. 
38. Rezaei, S., Amin, M., Moghaddam, M. and Mohamed, N. 2016. 3G post adoption users experience with telecommunications services: a partial least squares (PLS) path modelling approach. Nankai Business Review International. Vol. 7, No. 3, pp. 361-394.

39. Suh, B., Han, I. 2002. Effect of Trust on Consumer Acceptance of Internet Banking. Electronic Commerce Research and Applications. Vol. 1, No. 3, pp, 247-263.

40. Suriya, M., Mahalakshmi. V, \& Karthik, R., 2012. A study on customer perception towards internet banking. International Journal of Sales and Marketing Management Research and Development (IJSMMRD). Vol. 2, No. 3, pp. 15-34.

41. Venkatesh, V dan Davis, Fred D. 1996. "A Model of The Perceived Ease of Use: Development and Test." Decision Sciences, 27 (3), pp.451-481. 